\title{
Plasmid-encoded determinants for bacteriocin production and immunity in a Lactococcus lactis strain and purification of the inhibitory peptide
}

\author{
Alain Dufour, ${ }^{1}$ Dominique Thuault, ${ }^{2}$ Annie Boulliou, ${ }^{1}$ Claude M. Bourgeois ${ }^{2}$ and \\ Jean-Paul Le Pennec ${ }^{1 *}$
}

${ }^{1}$ URA 256, Laboratoire de Génétique Moléculaire, Université de Rennes I, Campus de Beaulieu, 35042 Rennes, France

${ }^{2}$ Association pour le Développement de la Recherche Appliquée aux Industries Agricoles et Alimentaires (ADRIA), 6 rue de l'Université, BP 313, 29191 Quimper, France

(Received 7 March 1991; revised 25 May 1991; accepted 1 July 1991)

\begin{abstract}
Lactococcin, a bacteriocin produced by Lactococcus lactis subsp. lactis ADRIA 85LO30, was purified as a 2.3-2.4 kDa peptide. Six non-bacteriocin-producing $\left(\mathrm{Bac}^{-}\right)$and non-immune $\left(\mathrm{Imm}^{-}\right)$strains were isolated after curing experiments. These strains had in common the loss or modification of two plasmids: pOS4 (32 kb) and pOS5 (70 kb). By comparing pOS5 and several modified plasmids, a DNA region from pOS5 of about $10 \mathrm{~kb}$, which was necessary for wild-type bacteriocin production and immunity, was identified.
\end{abstract}

\section{Introduction}

Many lactic acid bacteria produce bacteriocins or bacteriocin-like compounds (Geis et al., 1983; Klaenhammer, 1988). Bacteriocins are secreted proteins with bactericidal activity directed against species that are usually closely related to the producer bacterium (Tagg $e t$ $a l ., 1976)$. Lactic acid bacteria are used extensively in the food industry and bacteriocins or bacteriocin-producing strains are of great interest since they may prevent growth of spoilage and pathogenic bacteria. Nisin, the best-known bacteriocin of lactic acid bacteria, is thus used in dairy products (Hurst, 1981). Moreover, the genetic determinants for bacteriocin production and immunity have great potential as genetic markers. Several bacteriocins from lactococci have been characterized: they appear to form a heterogeneous group of proteins with respect to their molecular mass, biochemical properties, activity spectrum and mode of action (Klaenhammer, 1988).

Lactococci characteristically harbour a number of plasmid species, varying from two to eleven. Some of these plasmids carry determinants for identified traits such as lactose metabolism or proteolytic activity (McKay, 1983). Bacteriocin production and immunity are often associated with plasmid DNA. Production of bacteriocin by Lactococcus lactis subsp. lactis WM4, diplococcin by $L$. lactis subsp. cremoris 346 , and bacteriocin by $L$. lactis subsp. cremoris 9B4 were demonstrated to be encoded by plasmids of 135 (pNP2), 83 and $60 \mathrm{~kb}$ (p9B4-6) (Scherwitz et al., 1983; Davey, 1984; Neve et al., 1984), respectively. The genetic determinant for nisin production by $L$. lactis was found to be located on a plasmid (Tsai \& Sandine, 1987; Kaletta \& Entian, 1989) but recent investigations indicated that the nisin determinant may be a component of a large region of transmissible DNA that also contains nisin-resistance and sucrose-metabolizing genes (Dodd et al., 1990). Genetic determinants for nisin and bacteriocins from $L$. lactis WM4 and $L$. cremoris 9B4 have been cloned (Buchman et al., 1988; Kaletta \& Entian, 1989; Dodd et al., 1990; Scherwitz Harmon \& McKay, 1987; van Belkum et al., 1989), and the nisin gene and two bacteriocin operons from L. lactis subsp. cremoris 9B4 (van Belkum et al., 1991) have been sequenced.

This study was undertaken with the purpose of cloning the genetic determinant of a bacteriocin-like substance, designated lactococcin, produced by Lactococcus lactis subsp. lactis ADRIA 85LO30, one of the four strains of $L$. lactis that have been selected for their inhibitory activity against Clostridium tyrobutyricum (Thuault et al., 1991). This bactericidal effect against $C$. tyrobutyricum is of great interest since this bacterium provokes a late swelling during ripening of Emmental-type cheese when milk is contaminated with it. This paper reports the 
Table 1. Bacterial strains and plasmids

\begin{tabular}{|c|c|c|c|c|c|}
\hline $\begin{array}{l}\text { L. lactis } \\
\text { subsp. lactis strain }\end{array}$ & Derivation & Phenotype* & $\begin{array}{l}\text { Size of resident } \\
\text { plasmids }(\mathbf{k b})\end{array}$ & $\begin{array}{l}\text { Plasmid } \\
\text { designation }\end{array}$ & Reference \\
\hline ADRIA $85 L O 30$ & Wild-type strain & $\mathrm{Bac}^{+} \mathrm{Imm}^{+}$ & $2 \cdot 9,3 \cdot 0,3 \cdot 5,32,70$ & $\begin{array}{l}\text { pOS4 }(32 \mathrm{~kb}) \\
\text { pOS5 }(70 \mathrm{~kb})\end{array}$ & Thuault et al. (1991) \\
\hline C3015 & $\begin{array}{l}\text { Plasmid-cured derivative } \\
\text { of ADRIA 85LO30 }\end{array}$ & $\mathrm{Bac}^{+} \mathrm{Imm}^{+}$ & $2 \cdot 9,3 \cdot 0,3 \cdot 5,83$ & pES1 $(83 \mathrm{~kb})$ & This work \\
\hline $\mathrm{C} 2102$ & & $\mathrm{Bac}^{+} \mathrm{Imm}^{+}$ & $2 \cdot 9,3 \cdot 0,3 \cdot 5,74$ & pES2 (74 kb) & \\
\hline $\mathrm{C} 2122$ & & $\mathrm{Bac}^{+} \mathrm{Imm}^{+}$ & $2 \cdot 9,3 \cdot 0,3 \cdot 5,90$ & pES3 $(90 \mathrm{~kb})$ & \\
\hline C2109 & derivatives of $C 3015$ & $\mathrm{Bac}^{(-)} \mathrm{Imm}^{-}$ & $2 \cdot 9,3 \cdot 0,3 \cdot 5,62$ & pRS4 (62 kb) & This work \\
\hline C2111 & & $\mathrm{Bac}^{-} \mathrm{Imm}^{-}$ & $2 \cdot 9,3 \cdot 0,3 \cdot 5$ & & \\
\hline C2128 & & Bac $^{-}$Imm- $^{-}$ & $2 \cdot 9,3 \cdot 0$ & & \\
\hline IL1403 & & $\mathrm{Imm}^{-}$ & None & & Chopin et al. (1984) \\
\hline
\end{tabular}

* Bac, bacteriocin; Imm, immunity.

purification of lactococcin and the putative assignment of the gene to a high-molecular-mass plasmid as determined by curing experiments and variant studies.

\section{Methods}

Bacterial strains, plasmids and culture conditions. The strains used and their resident plasmids are listed in Table 1. L. lactis IL1403 (Chopin et $a l ., 1984)$ was inhibited by the bacteriocin $\left(\mathrm{Imm}^{-}\right)$and was used as an indicator strain of bacteriocin activity. Bacteria were propagated at $30{ }^{\circ} \mathrm{C}$ in glucose M17 broth (M17G) (Terzaghi \& Sandine, 1975). For subsequent bacteriocin purification, the producing strain was grown at $30^{\circ} \mathrm{C}$ in a 2-litre fermenter (Setric Génie industriel) in which the pH was maintained at 5.2 by addition of $\mathrm{NH}_{4} \mathrm{OH}$. The medium used in this case was CG broth (Bhunia et al., 1987) modified as follows: glucose and magnesium sulphate were used at 2 and $0.06 \%(w / v)$, respectively; $0.02 \% \mathrm{~K}_{2} \mathrm{HPO}_{4}, 0.02 \% \mathrm{KH}_{2} \mathrm{PO}_{4}$ and $0.003 \%$ iron sulphate were added, and disodium phosphate was omitted.

Bacteriocin production and immunity. In order to test for bacteriocin production $\left(\mathrm{Bac}^{+}\right)$, two methods were used. The first one was a solid medium test. Decimal dilutions of bacteria were plated onto M17G $\operatorname{agar}(1.5 \%, w / v)$ and overlaid with M17G soft agar $(0.7 \%$, w/v). After $24 \mathrm{~h}$ incubation at $30^{\circ} \mathrm{C}$, the plates containing up to 20 colonies were overlaid with M17G agar $(1.5 \%$, w/v) seeded with a culture of the indicator organism $\left(\mathrm{Imm}^{-}\right)$and incubated for an additional $24 \mathrm{~h}$ at $30^{\circ} \mathrm{C}$. Colonies surrounded by a clear zone of inhibition were $\mathrm{Bac}^{+}$. In the second method, culture supernatant was assayed for the presence of the bacteriocin. Bacteria were grown to late exponential phase and cells removed by centrifugation. The supernatant was sterilized by filtration through a $0.45 \mu \mathrm{m}$ membrane filter and $100 \mu \mathrm{l}$ aliquots were poured into wells of $\mathrm{M} 17 \mathrm{G}$ agar $(1.5 \%, \mathrm{w} / \mathrm{v})$ plate previously seeded with a culture of the indicator strain. After overnight incubation at $30^{\circ} \mathrm{C}$, wells surrounded by clear zones of inhibition indicated bacteriocin activity (Tagg \& McGiven, 1971). To quantify the activity, twofold dilutions of supernatant culture fluid were tested in the same way. The reciprocal of the greatest inhibitory dilution was used to calculate arbitrary activity units (AU) per $\mathrm{ml}$ (Mayr-Harting et al., 1972).

Bacteriocin immunity $\left(\mathrm{Imm}^{+}\right.$) was examined by using the second method, in which the indicator strain was replaced by the strain to be characterized.

Purification of bacteriocin. The supernatant of L. lactis ADRIA $85 \mathrm{LO} 30$ bacteria grown for $24 \mathrm{~h}$ in modified CG broth was recovered by centrifugation $(6000 \mathrm{~g}$ for $10 \mathrm{~min}$ ) and extensively dialysed (cut-off $6.0 \mathrm{kDa}$ ) against sodium acetate buffer $(50 \mathrm{~mm}, \mathrm{pH} 4.5)$. Cationexchange chromatography (CM-Trisacryl, IBF) was performed as recommended by the supplier. Positively charged proteins were eluted by a sodium chloride gradient $(0-0 \cdot 4 \mathrm{M})$. Fractions $(12 \mathrm{ml})$ were collected and tested for bacteriocin activity as above. The active fractions were dialysed (cut-off $2.0 \mathrm{kDa}$ ) against potassium phosphate buffer ( $10 \mathrm{mM}, \mathrm{pH} 6.5)$ and lyophilized. The proteins were dissolved in $50 \mathrm{~mm}$-ammonium bicarbonate $\mathrm{pH} 7.8$ and applied to a gel filtration column (Sephadex G-50, Pharmacia). Fractions (4 ml) containing bacteriocin activity were lyophilized. The column was calibrated using gel filtration molecular mass markers ranging from 6.5 to $66 \mathrm{kDa}$ (MWGF-70 kit, Sigma). Protein concentrations were determined by the method of Bradford (1976) with bovine serum albumin as standard. Proteins were analysed by urea sodium dodecyl sulphate polyacrylamide gel electrophoresis (urea-SDS-PAGE) as described by Swank \& Munkres (1971). The gel was stained by the method of Neuhoff $e t$ al. (1988). Size standards were five myoglobin chains of molecular mass 2.5-16.9 kDa (LKB).

Curing experiments. The method described by Sinha (1989) was used. The strains were grown at $30^{\circ} \mathrm{C}$ in an unbuffered medium (M17-: M17 without phosphate) and maintained at the same temperature for an extended period (at least $96 \mathrm{~h}$ ). The bacteria were plated and screened either for the loss of plasmid species by plasmid pattern studies, or for the loss of the $\mathrm{Bac}^{+}$phenotype by the overlay method described above. In the second case, colonies not surrounded by a clear zone of inhibition were picked for further investigation.

Plasmid DNA isolation and analyses. Plasmids were extracted as described by Anderson \& McKay (1983). Purification of a specific plasmid from a preparation containing several plasmid species was performed by sucrose-gradient purification (Anderson \& McKay, 1984). Preparations containing plasmids from 2 to $90 \mathrm{~kb}$ were centrifuged in a Beckman SW41 rotor at 36000 r.p.m. for $3 \mathrm{~h}$ at $20^{\circ} \mathrm{C}$ through a $15-35 \%(w / v)$ sucrose gradient prepared in $1.0 \mathrm{M}-\mathrm{NaCl}$, $20 \mathrm{~mm}$-Tris/HCl $\mathrm{pH} \mathrm{8.0,5} \mathrm{mm}$-EDTA $\mathrm{pH} 8.0$. Gradients were fractionated and analysed by agarose gel electrophoresis. Fractions of interest were dialysed against TE buffer $(10 \mathrm{mM}-\mathrm{Tris} / \mathrm{HCl} \mathrm{pH} 8.0$, 1 mM-EDTA pH 8.0). DNA was concentrated by n-butanol extractions, precipitated with ethanol and dissolved in TE buffer.

Restriction endonucleases were used as recommended by the suppliers. Plasmids and DNA restriction fragments were analysed by electrophoresis in $0.7-1.0 \%(\mathrm{w} / \mathrm{v})$ agarose gels (Maniatis et al., 1982). Sizes of supercoiled plasmid DNA were determined by using plasmids from $E$. coli or $L$. lactis as standards. Linear DNA fragment sizes were 

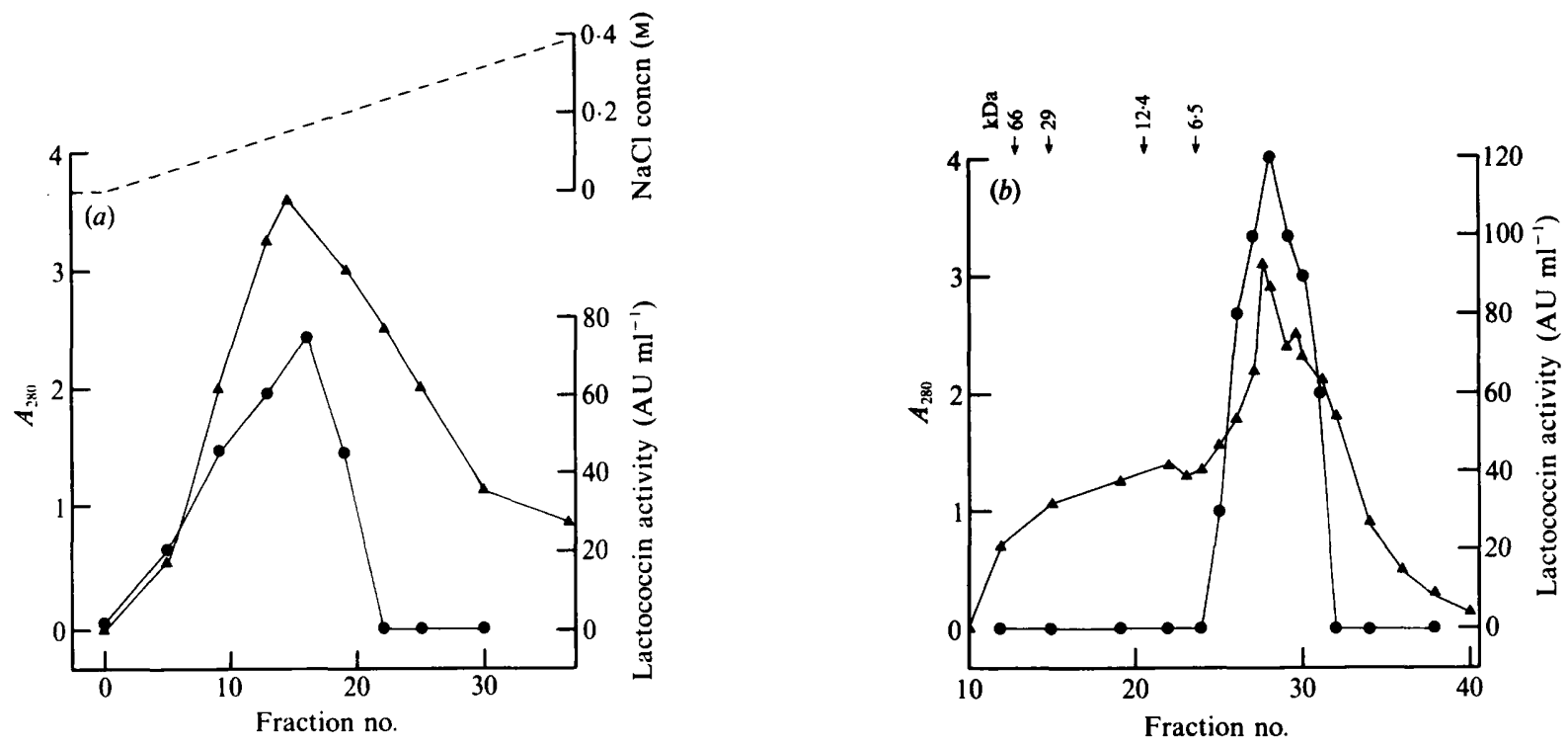

Fig. 1. Elution of lactococcin activity from chromatography columns. (a) Cation-exchange column (CM-Trisacryl). (b) Gel filtration column (Sephadex G-50) loaded with pooled fractions 5-20 from (a). $\Delta$, Absorbance at $280 \mathrm{~nm}$ (arbitrary units); $\boldsymbol{O}$, lactococcin activity; ---, linear $\mathrm{NaCl}$ gradient; $\downarrow$, elution peaks of molecular mass markers.

determined using bacteriophage $\lambda$ DNA digested with BstEII or EcoRI as standards. Hybridization experiments were performed as described by Maniatis et al. (1982), using nylon membranes (Hybond-N, Amersham): DNA probes were purified from agarose gels by using Gene Clean (Bio 101) and labelled by the random-priming method (Feinberg \& Vogelstein, 1984).

\section{Results and Discussion}

\section{Purification of lactococcin}

The purification of the bacteriocin-like protein was undertaken to further characterize it and to determine an amino acid sequence from which an oligonucleotidic probe could be constructed to analyse the corresponding gene.

To minimize the amount of contaminating proteins, lactococcin was purified from supernatants of broth cultures prepared in modified CG medium. Since lactococcin was shown to be produced during the exponential phase of bacterial growth (Thuault et al., 1991), the Lactococcus was cultured in a fermenter at a constant $\mathrm{pH}$ of $5 \cdot 2$ to avoid growth inhibition caused by acidification of the medium due to the production of lactic acid. The culture supernatant was equilibrated at pH 4.5 by dialysis and directly applied to a cationexchange column. No protein concentration step was performed before chromatography since the proteins retained by the column were thus concentrated. A single protein peak containing bacteriocin activity was eluted between 0 and $0 \cdot 4 \mathrm{M}-\mathrm{NaCl}$ (Fig. $1 a$ ). Urea-SDS-PAGE analysis (Fig. 2, lane 1) showed a very heterogeneous

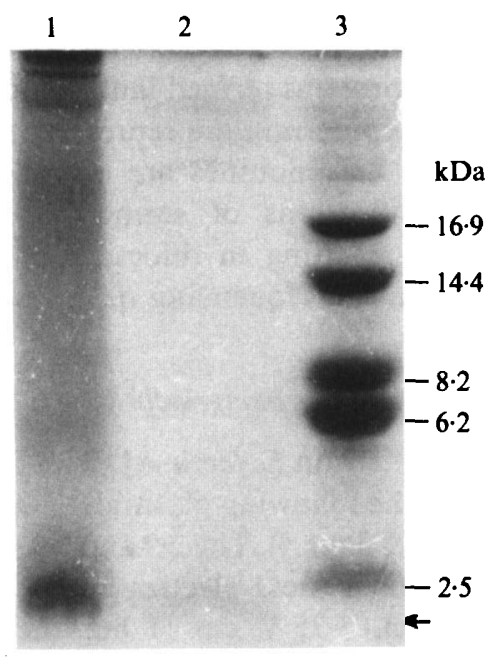

Fig. 2. Urea-SDS-PAGE of proteins from culture supernatant of $L$. lactis ADRIA 85LO30 during the purification of lactococcin. Lanes: 1 , $\mathrm{Bac}^{+}$fractions after cation-exchange chromatography; 2, $\mathrm{Bac}^{+}$ fractions after gel filtration chromatography; 3, molecular mass markers. The arrow indicates the purified peptide.

protein population. When active fractions were concentrated and applied to a Sephadex G-50 column, several protein peaks were obtained; the inhibitory activity was contained in the most prominent one (Fig. $1 b$ ). The molecular mass of proteins in the major active fractions was estimated as approximately $2 \cdot 3 \mathrm{kDa}$ by comparison with gel filtration size standards. Urea-SDS-PAGE analysis (Fig. 2, lane 2) showed a single protein band of around $2.4 \mathrm{kDa}$, confirming this estimate. 
Table 2. Purification of lactococcin

\begin{tabular}{|c|c|c|c|c|c|c|c|}
\hline Purification step & $\begin{array}{c}\text { Volume } \\
\text { (ml) }\end{array}$ & $\begin{array}{l}\text { Lactococcin } \\
\text { activity } \\
\left(\mathrm{AU} \mathrm{\textrm {ml } ^ { - 1 }}\right)\end{array}$ & $\begin{array}{c}\text { Total } \\
\text { lactococcin } \\
\text { activity } \\
\text { (AU) }\end{array}$ & $\begin{array}{c}\text { Protein } \\
\text { concentration } \\
\left(\mathrm{mg} \mathrm{ml}^{-1}\right)\end{array}$ & $\begin{array}{l}\text { Amount of } \\
\text { protein } \\
(\mathrm{mg})\end{array}$ & $\begin{array}{c}\text { Specific } \\
\text { activity } \\
\left(\mathrm{AU} \mathrm{mg}^{-1}\right)\end{array}$ & $\begin{array}{l}\text { Purification } \\
\quad \text { (-fold) }\end{array}$ \\
\hline Culture supernatant & 850 & 80 & 68800 & $0 \cdot 3$ & 255 & 270 & 1 \\
\hline Dialysis (cut-off $6 \mathrm{kDa}$ ) & 900 & 75 & 67500 & 0.25 & 225 & 300 & $1 \cdot 1$ \\
\hline Cation-exchange chromatography & 190 & 45 & 8550 & 0.03 & $5 \cdot 7$ & 1500 & $5 \cdot 5$ \\
\hline Gel-filtration chromatography & 39 & 80 & 3100 & 0.02 & 0.8 & 3900 & 14.5 \\
\hline
\end{tabular}

A scaled-down purification of lactococcin is represented in Table 2. The final purification was 14.5 -fold. It is noteworthy that no significant inhibitory activity was lost during the dialysis step with a $6.0 \mathrm{kDa}$ cut-off, although the molecular mass of lactococcin was found to be around $2.4 \mathrm{kDa}$. A possible explanation is that lactococcin may be in a multimeric form in the culture supernatant. We were not able to determine an amino acid sequence of the purified peptide by Edman degradations. This may have been due to contaminating proteins or to the presence of lanthionines in lactococcin. These unusual amino acids are characteristic of a class of small bactericidal proteins termed lantibiotics, of which nisin, subtilin and epidermin are representatives (Buchman et al., 1988). Lanthionines are obtained by posttranslational modifications of serine, threonine and cysteine residues, resulting in thioether cross-linkages which may explain the sequencing difficulties.

\section{Plasmid localization of the bacteriocin gene}

The wild-type $\mathrm{Bac}^{+}$strain L. lactis ADRIA 85LO30 was shown to harbour the following plasmids: $2 \cdot 9,3 \cdot 0,3 \cdot 5,32$ and $60-70 \mathrm{~kb}$ (Fig. 3, lane 4). The 2.9 and $3.0 \mathrm{~kb}$ plasmids were not separated in these electrophoretic conditions $\left(0.75 \%\right.$ agarose gel, $\left.3.75 \mathrm{~V} \mathrm{~cm}^{-1}\right)$ but they could be distinguished by electrophoresis on a higher percentage agarose gel. Restriction analysis showed that the bands of $60-70 \mathrm{~kb}$ were due to a unique plasmid species of about $70 \mathrm{~kb}$ (see below). The 32 and $70 \mathrm{~kb}$ plasmids were designated pOS4 and pOS5, respectively. Curing experiments were undertaken to investigate whether bacteriocin production could be correlated with a specific plasmid. The method of Sinha (1989) was chosen because of the described high frequency of plasmid elimination and of its apparent non-mutagenicity compared with methods involving mutagenic chemicals. The plasmid content and the phenotype of the strains described below are summarized in Table 1.

The first experiment was performed with a $96 \mathrm{~h}$ incubation time. Of 30 colonies screened by plasmid extractions, one had a modified plasmid content. This
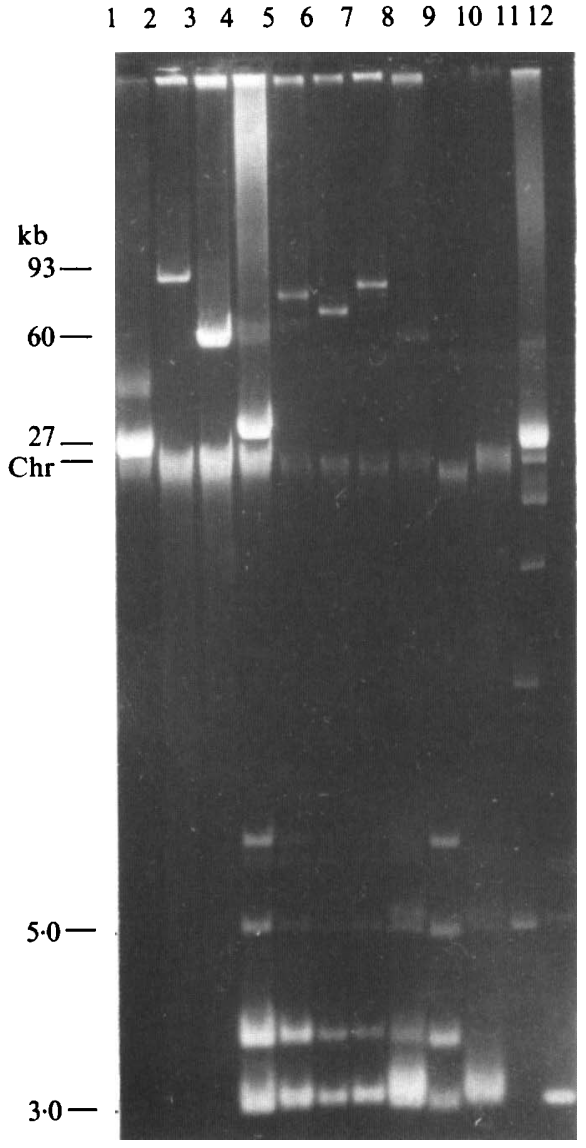

Fig. 3. Agarose gel electrophoresis of plasmid DNA from $L$. lactis ADRIA 85LO30 and derived strains. Lanes: 4, ADRIA 85LO30 (pOS4, pOS5); 5, C3015 (pES1); 6, C2102 (pES2); 7, C2122 (pES3); 8, C2109 (pRS4); 9, C2111; 10, C2128. Molecular size markers: plasmid DNA from L. lactis or E. coli: Lanes: 1, pAM $\beta 1(27 \mathrm{~kb}) ; 2$, pR483 (93 kb); 3, pRP1 (60 kb); 11, pIL253 (5.0 kb); 12, pBluescript (3.0 kb, Stratagene). Chr, chromosomal DNA.

strain, designated C3015, had lost pOS4 $(32 \mathrm{~kb})$ but an additional plasmid species of $83 \mathrm{~kb}$ appeared, named pES1 (Fig. 3, lane 5). L. lactis C3015 presented a $\mathrm{Bac}^{+}$ $\mathrm{Imm}^{+}$phenotype. pOS4 was therefore not needed for bacteriocin production or immunity, unless pOS4 or a part of it was included in pES1. 

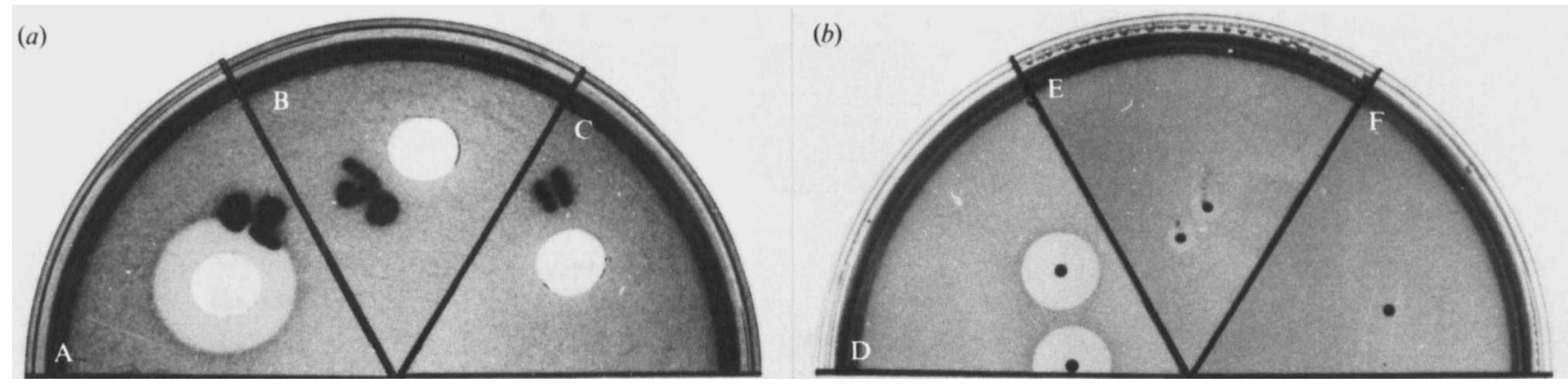

Fig. 4. Inhibitory activity of various strains derived from L. lactis ADRIA $85 \mathrm{LO} O 30$ tested against L. lactis IL1403 (Imm $\left.{ }^{-}\right)$by (a) culture supernatant diffusion or (b) solid agar medium test. A, D, C2102; B, E, C2109; C, F, C2111. Inhibitory activity is shown by a clear zone.

Subsequent curing experiments were performed with C3015. The incubation time had to be increased to $480 \mathrm{~h}$ to isolate new variant strains. The screening was performed either by Bac phenotype analyses or by plasmid preparations. By the first method, six $\mathrm{Bac}^{-}$ colonies were isolated in three experiments. The $\mathrm{Bac}^{-}$ character of one of these strains, designated C2111, is shown in Fig. 4(C, F). The six Bac ${ }^{-}$strains were all sensitive to lactococcin $\left(\mathrm{Imm}^{-}\right)$. Each strain was cured of all high-molecular-mass plasmids. Four strains harboured the 2.9, 3.0 and $3.5 \mathrm{~kb}$ plasmids (for example C2111, Fig. 3, lane 9) while the two other strains contained only the 2.9 and $3.0 \mathrm{~kb}$ ones (for example C2128, Fig. 3, lane 10). These observations suggested that the plasmids pOS4 or pOS5 were involved in bacteriocin production and immunity. By the second screening method, the plasmid content of 58 colonies was analysed after an incubation of $192 \mathrm{~h}$. With respect to C3015, all colonies showed a modified plasmid electrophoretic pattern. The differences were exclusively located in the high-molecular-mass plasmid region. Three types of plasmid patterns were observed (Fig. 3, lanes 6 to 8). The strains $\mathrm{C} 2102$ and C2122, representative of two plasmid patterns, harboured high-molecularmass plasmids of 74 (pES2) (Fig 3, lane 6) to $90 \mathrm{~kb}$ (pES3) (Fig. 3, lane 7) and had a $\mathrm{Bac}^{+} \mathrm{Imm}^{+}$phenotype (the $\mathrm{Bac}^{+}$character of $\mathrm{C} 2102$ is shown in Fig. 4, A, D). One strain, designated $C 2109$, harboured a unique highmolecular-mass plasmid of reduced size $(62 \mathrm{~kb})$, pRS4 (Fig. 3, lane 8). Strain C2109 was found to be $\mathrm{Bac}^{-}$when the bacteriocin activity of the culture supernatant was tested (Fig. 4, B), but was shown to induce a small inhibition halo when the test was done by the overlay method (Fig. 4, E). This inhibitory activity could be concentrated from a liquid medium culture by ultrafiltration and may result from a residual bacteriocin production. The Bac phenotype of $\mathrm{C} 2109$ was denoted $\mathrm{Bac}^{(-)}$. L. lactis $\mathrm{C} 2109$ could be inhibited by lactococcin $\left(\mathrm{Imm}^{-}\right)$, but must have a sufficient immunity level to survive its own bacteriocin production. The $\mathrm{Bac}^{(-)} \mathrm{Imm}^{-}$ phenotype of $\mathrm{C} 2109$ may result from the reduced-size plasmid pRS4. This hypothesis is in agreement with the association of lactococcin production and immunity with the large plasmid species.

\section{Identification of a region of pOS5 involved in bacteriocin production and immunity}

To further characterize and compare the large plasmids from the different $\mathrm{Bac}^{+}$strains and $\mathrm{C} 2109\left(\mathrm{Bac}^{(-)}\right)$, DNA restriction analysis of these purified plasmids was performed. The results from BamHI digests are presented in Fig. 5(a). By sucrose-gradient centrifugation we were able to separate the plasmids of around $70 \mathrm{~kb}$ from the $2.9,3.0$ and $3.5 \mathrm{~kb}$ ones, but not from pOS4 (32 kb), only present in L. lactis ADRIA 85LO30. Thus, when digesting large plasmids from this strain, fragments of greater intensity arising from pOS4 were observed. For example, restriction of pOS4 by BamHI generated two DNA fragments of 20 and $13 \mathrm{~kb}$ (Fig. $5 a$, lane 1).

Similar BamHI restriction patterns were obtained with the large plasmids from the various strains (Fig. 5a), leading us to conclude that the various high-molecularmass plasmids were derived from pOS5. The sum of the sizes of the DNA restriction fragments was in good agreement with the estimated size of the native plasmids and corresponded to a unique $60-90 \mathrm{~kb}$ plasmid in each strain. When comparing the BamHI restriction fragments (Fig. $5 a$ ), we observed in the $\mathrm{Bac}^{(-)}$pRS4 plasmid (lane 5) the loss of three fragments of $4 \cdot 5,3 \cdot 1$ and $2 \cdot 1 \mathrm{~kb}$ which were present in pOS5 and the pOS5-derived plasmids of all $\mathrm{Bac}^{+}$strains (lanes 1-4). These fragments were cloned in $E$. coli and used as probes in Southern hybridization experiments. The results of hybridizations with DNA of Fig 5(a) are presented in Fig. 5(b-d). Each probe hybridized with its corresponding BamHI fragment in lanes 1-4, but there was no similar hybridization 

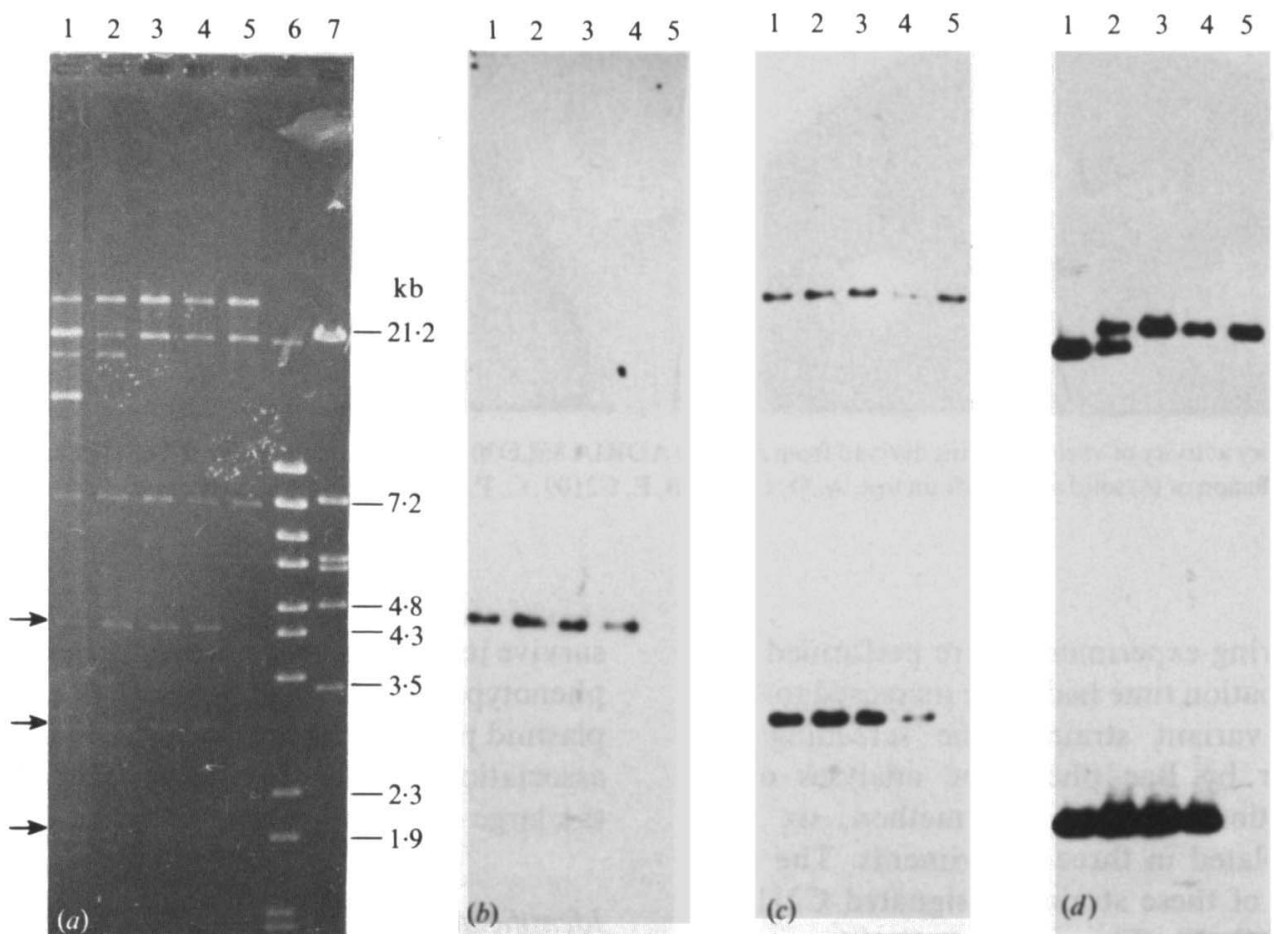

Fig. 5. (a) Agarose gel electrophoresis of BamHI-digested high-molecular-mass plasmids from L. lactis ADRIA 85 LO30 and derived strains. $(b, c, d)$ Autoradiograms resulting from Southern hybridizations of panel $(a)$ with the $4.5 \mathrm{~kb}(b), 3.1 \mathrm{~kb}(c)$ or $2.1 \mathrm{~kb}(d)$ fragments of pES2 as ${ }^{32}$ P-labelled probes. Lanes: 1, pOS4 and pOS5 (ADRIA 85LO30); 2, pES1 (C3015); 3, pES2 (C2102); 4, pES3 (C2122); 5 , pRS4 (C2109). All strains are Bac $\mathrm{Imm}^{+}$, except C2109 $\left(\mathrm{Bac}^{(-)} \mathrm{Imm}^{-}\right)$. Lanes 6 and 7, molecular size markers: bacteriophage $\lambda$ DNA digested with BstEII or EcoRI, respectively. The arrows indicate the DNA fragments deleted in pRS4 and used as probes in panels $(b)$, $(c)$ and $(d)$.

in lanes 5 , confirming that the three fragments used as probes were present in all $\mathrm{Bac}^{+}$high-molecular-mass plasmids, and absent in the $\mathrm{Bac}^{(-)}$plasmid pRS4. It is noteworthy that the $3 \cdot 1$ and $2.1 \mathrm{~kb}$ probes strongly crosshybridized with other BamHI restriction fragments. By hybridizing these probes with EcoRI or HindIII digests of the various plasmids, the three BamHI fragments were shown to be contiguous, forming a single plasmid region (data not shown). A region of the $\mathrm{Bac}^{+}$plasmids pOS5, pES1, pES2 and pES3, which was deleted in the $\mathrm{Bac}^{(-)}$ plasmid pRS4, was thus identified. This region probably contains genetic information which is required for lactococcin production and immunity in the wild-type $\mathrm{Bac}^{+} \mathrm{Imm}^{+}$strain.

\section{Conclusions}

Curing experiments indicated that production of lactococcin, a bacteriocin-like peptide of about $2.4 \mathrm{kDa}$, and immunity are probably associated with a plasmid from L. lactis subsp. lactis ADRIA 85LO30. The curing method used resulted not only in elimination of plasmid species (six Bac- $\mathrm{Imm}^{-}$strains were cured of all highmolecular-mass plasmid species), but also in modifications of the plasmid pOS5 $(70 \mathrm{~kb})$. No similar observation has previously been reported with this method. When comparing pRS4, a deleted $\mathrm{Bac}^{(-)} \mathrm{Imm}^{-}$plasmid, with $\mathrm{Bac}^{+}$plasmids, we identified in pOS5 a DNA region of about $10 \mathrm{~kb}$ probably necessary for lactococcin production and immunity.

These results suggest, without formal proof, that genetic determinants for bacteriocin production and immunity are localized on pOS5, and are at least partially included in the $10 \mathrm{~kb}$ region. Work currently in progress is aimed at isolating the genetic determinant for lactococcin production and immunity by cloning fragments of the $\mathrm{Bac}^{+}$plasmid into lactic acid bacteria and searching for a clone able to express the gene.

This work was supported by grants from the Ministère de la Recherche et de la Technologie (no. 88.T.0806) and a fellowship (A.D.) from the Région Bretagne. We thank Alain and MarieChristine Chopin for providing strains and plasmids, Carlos Blanco and Michel Gautier for the critical reading of this manuscript, Anne Cario for technical assistance, and Louis Communier for the photographs. 


\section{References}

ANDERSON, D. G. \& MCKAY, L. L. (1933). Simple and rapid method for isolating large plasmid DNA from lactic streptococci. Applied and Environmental Microbiology 46, 549-552.

ANDERSON, D. G. \& MCKAY, L. L. (1984). Genetic and physical characterization of recombinant plasmids associated with cell aggregation and high-frequency conjugal transfer in Streptococcus lactis ML3. Journal of Bacteriology 158, 954-962.

van Belkum, M. J., Hayema, B. J., Geis, A., KoK, J. \& Venema, G. (1989). Cloning of two bacteriocin genes from a lactococcal bacteriocin plasmid. Applied and Environmental Microbiology 55, $1187-1191$.

van BelKum, M. J., Hayema, B. J., Jeeninga, R. E., KoK, J. \& VENEMA, G. (1991). Organisation and nucleotide sequences of two lactococcal bacteriocin operons. Applied and Environmental Microbiology 57, 492-498.

Bhunia, A. K., Johnson, M. C. \& RaY, B. (1987). Direct detection of an antimicrobial peptide of Pediococcus acidilactici in sodium dodecyl sulfate-polyacrylamide gel electrophoresis. Journal of Industrial Microbiology 2, 319-322.

BRADFORD, M. M. (1976). A rapid and sensitive method for the quantitation of microgram quantities of protein utilising the principle of protein-dye binding. Analytical Biochemistry 72, 248254.

Buchman, G. W., Banerjee, S. \& Hansen, J. N. (1988). Structure, expression, and evolution of a gene encoding the precursor of nisin, a small protein antibiotic. Journal of Biological Chemistry 263, 1626016266.

Chopin, A., Chopin, M. C., Moillo-Batt, A. \& Langella, P. (1984). Two plasmid determined restriction and modification systems in Streptococcus lactis. Plasmid 11, 260-263.

DAVEY, G. P. (1984). Plasmid associated with diplococcin production in Streptococcus cremoris. Applied and Environmental Microbiology 48, 895-896.

DodD, H. M., HoRn, N. \& Gasson, M. J. (1990). Analysis of the genetic determinant for production of the peptide antibiotic nisin. Journal of General. Microbiology 136, 555-566.

Feinberg, A. P. \& Vogelstein, B. (1984). A technique for radiolabelling DNA restriction endonuclease fragments to high specific activity. Analytical Biochemistry 132, 6-13.

Geis, A., Singh, J. \& Teuber, M. (1983). Potential of lactic streptococci to produce bacteriocin. Applied and Environmental Microbiology 45, 205-211.

HURST, A. (1981). Nisin. Advances in Applied Microbiology 27, 85-123.

Kaletta, C. \& Entian, K. D. (1989). Nisin, a peptide antibiotic: cloning and sequencing of the nis $\mathrm{A}$ gene and posttranslational processing of its peptide product. Journal of Bacteriology 171, 15971601.

KlaEnhammer, T. R. (1988). Bacteriocins of lactic acid bacteria. Biochimie 70, 337-349.

Maniatis, T., Fritsch, E. F. \& SAmbrook, J. (1982). Molecular Cloning: a Laboratory Manual. Cold Spring Harbor, NY: Cold Spring Harbor Laboratory.

Mayr-Harting, A., Hedges, J. A. \& Berkeley, R. L. W. (1972). Methods for studying bacteriocins. Methods in Microbiology 7, 315-422.

McKAY, L. L. (1983). Functional properties of plasmids in lactic streptococci. Antonie van Leeuwenhoek 49, 259-274.

Neuhoff, V., Arold, N., Taube, D. \& Ehrhardt, W. (1988). Improved staining of proteins in polyacrylamide gels including isoelectric focusing gels with clear background at nanogram sensitivity using Coomassie Brilliant Blue G-250 and R-250. Electrophoresis 9, 255-262.

Neve, H., Geis, A. \& Teuber, M. (1984). Conjugal transfer and characterization of bacteriocin plasmids in group $\mathbf{N}$ (lactic acid) streptococci. Journal of Bacteriology 157, 833-838.

Scherwitz, K. M., BaldWIN, K. A. \& McKay, L. L. (1983). Plasmid linkage of a bacteriocin-like substance in Streptococcus lactis subsp. diacetylactis strain WM4: transferability to Streptococcus lactis. Applied and Environmental Microbiology 45, 1506-1512.

SCherwitz HaRmon, K. \& McKaY, L. L. (1987). Restriction enzyme analysis of lactose and bacteriocin plasmids from Streptococcus lactis subsp. diacetylactis WM4 and cloning of $B c l$ I fragments coding for bacteriocin production. Applied and Environmental Microbiology 53, 1171-1174.

SiNHA, R. P. (1989). A new simple method of curing plasmids in lactic streptococci. FEMS Microbiology Letters 57, 349-352.

SWANK, R. W. \& MUNKRES, K. D. (1971). Molecular weight analysis of oligopeptides by electrophoresis in polyacrylamide gel with sodium dodecyl sulfate. Analytical Biochemistry 39, 462-477.

TAGG, J. R. \& MCGIVEN, A. R. (1971). Assay system for bacteriocins. Applied Microbiology 21, 943.

TAGG, J. R., Dajani, A. S. \& Wannamaker, L. W. (1976). Bacteriocins of Gram-positive bacteria. Bacteriological Reviews 40, 722-756.

TerzaGHI, B. E. \& SANDINE, W. E. (1975). Improved medium for lactic streptococci and their bacteriophages. Applied Microbiology 29, 807813.

Thuault, D., Beliard, E., Le Guern, J. \& Bourgeois, C. M. (1991). Inhibition of Clostridium tyrobutyricum by bacteriocin-like substances produced by lactic acid bacteria. Journal of Dairy Science 74, 1145-1150.

TSAI, H. J. \& SANDINE, W. E. (1987). Conjugal transfer of nisin plasmid genes from Streptococcus lactis 7962 to Leuconostoc dextranicum 181. Applied and Environmental Microbiology 53, 352-357. 